\title{
Stage II Vaginal Cancer AJCC v8
}

National Cancer Institute

\section{Source}

National Cancer Institute. Stage II Vaginal Cancer A/CC v8. NCI Thesaurus. Code

C139661.

Stage II includes: IIA:T2a, N0, M0; IIB: T2b, N0, M0. T2a: Tumor invading paravaginal tissues but not to pelvic wall, measuring $2.0 \mathrm{~cm}$ or less. T2 b: Tumor invading paravag inal tissues but not to pelvic wall, measuring more than $2.0 \mathrm{~cm}$. N0: No regional lymph node metastasis. M0: No distant metastasis. (AJCC 8th Ed.) 